\title{
Decantando a República: um encontro entre o historiador e o compositor popular
}

Decantando a República: a meeting between the historian and the popular composer

Bruno Viveiros Martins*

\section{RESUmo}

$\mathrm{O}$ artigo tem por objetivo analisar as possibilidades de construção e divulgação do conhecimento histórico realizadas pelo programa Decantando a República, veiculado pela Rádio UFMG Educativa 104,5 FM. Criado em 2005, o programa propõe um diálogo entre a linguagem musical e o contexto histórico, social e político no qual ela se faz presente. Dessa forma, a canção é pensada como um suporte de circulação de ideias, princípios e valores. O compositor popular seria um intérprete capaz de pensar o país e sua história. Nesse caso, sua narrativa percorre os hiatos do tempo à procura de eventos, personagens e ações com os quais ele constrói uma rede emaranhada e descontínua de experiências históricas.

Palavras-chave: rádio; ensino de história; canção popular.

\section{Abstract}

This article aims to analyze the possibilities of construction and dissemination of the historical knowledge made by the program Decantando a Repúbli$c a$, transmitted by UFMG Educational Radio 104.5 FM. Created in 2005, the program proposes a dialogue between musical language and the historical, social and political context in which she is present. In this way, the song is thought as a support of the movement of ideas, principles and values. The popular composer would be a performer capable of thinking the country and its history. In this case, his narrative goes through time gaps searching for events, characters and actions with which he builds a tangled and discontinuous web of historical experiences.

Keywords: radio; history teaching; popular song.

\footnotetext{
* Mestre em História pela Universidade Federal de Minas Gerais (UFMG). Doutorando do Programa de Pós-Graduação em História da Universidade Federal de Minas Gerais (UFMG). Belo Horizonte, MG, Brasil. brviveiros@gmail.com
} 
Caríssimos ouvintes, obrigado

Pela atenção a mim tão dispensada

Nossa programação se encerra agora

Mas de teimosa, volta amanhã

Plateia de meus sonhos, tão amada

O canto é o chamado pra viver

Quando o show terminar, levem pra casa

Não deixem que ele morra por aqui

Milton Nascimento e Tunai

Rádio Experiência, 1985

O programa Decantando a República estreou na Rádio UFMG Educativa, 104,5 FM, em setembro de 2005. O objetivo era estabelecer um diálogo entre a canção popular e a história do Brasil, a ser veiculado para um público amplo e diverso, formado não apenas por alunos e professores interessados em uma nova ferramenta de ensino e aprendizagem. A história aqui tratada seria um conhecimento construído de forma interativa, com ênfase na reflexão sobre o lugar e o papel do sujeito na criação de um saber crítico e participativo, capaz de integrá-lo - na condição de cidadão apto a tomar decisões de forma livre e autônoma - ao mundo público, a uma vida ética.

\section{HistóRIA E CANÇÃo}

O compositor utiliza estratégias conceituais e modos linguísticos que definem seus discursos narrativos, denominados "tropos de linguagem", ou seja, a estrutura verbal em que o autor encadeia os conceitos argumentativos e procedimentos retóricos, sem os quais nenhuma narrativa histórica poderia existir. Ao se estabelecerem entre a escrita imaginativa e realista, entre o discurso ficcional e factual, os cancionistas manejam a linguagem musical não como uma forma vazia, a ser preenchida com eventos e fatos históricos. Escolhas de estilo e elaboração de enredos, além do conteúdo interpretativo - constituído por ironias, sátiras, metonímias, metáforas - interferem diretamente na maneira como uma canção expressa as ideias de um compositor. Por meio da identificação dos tropos de linguagem utilizados pela canção popular, é possível 
analisar as visões de mundo dispostas para além da superfície manifesta textualmente. Para tanto, segundo Hayden White:

Na passagem do estudo de um arquivo para a composição de um discurso e para a sua tradução na forma escrita, os historiadores têm de empregar as mesmas estratégias da figuração linguística utilizadas por escritores imaginativos para dotar seus discursos daqueles tipos de significados latentes, secundários ou conotativos que requererão que suas obras não só sejam recebidas como mensagens, mas sejam lidas como estruturas simbólicas. (White, 1994, p.29)

Em virtude das características particulares da canção popular brasileira, pensada como uma forma peculiar de narrativa que congrega versos, melodias e performance interpretativa, o programa Decantando a República visa estabelecer uma metodologia que tem como eixo a integração entre a canção e a sua realidade histórica. Dessa forma, buscamos a intertextualidade entre a obra musical e a época em que ela encontra um sentido próprio e particular, principalmente, em relação ao seu contexto político, cultural e social.

Para Quentin Skinner (2000), ao investigar certas convenções linguísticas, crenças e práticas próprias aos atores concretos que respondem às questões imediatas de um tempo específico, o historiador deve procurar identificar os contextos que dão sentido ao texto. Para o autor, a interpretação de um "ato linguístico”, uma canção, por exemplo, deve passar não apenas pela análise do seu conteúdo, mas também pela forma como o ato foi proferido. Isso quer dizer que uma mesma palavra, frase ou verso podem ser pronunciados de diversas maneiras.

Skinner sugere, portanto, uma maior atenção para a maneira como o conteúdo é proferido, assim como para os acentos interpretativos de um texto (enfático, irônico, em forma de conselho, tom de súplica ou ordem), elementos definidores para a sua interpretação. Essa atenção ao modo como um narrador expõe uma ideia ou defende um argumento, assim como as palavras e sentenças que compõem um discurso, seria fundamental para compreensão dos "atos de fala", pois através dele o autor imprime um sentido particular à comunicação oral ou escrita, alterando o conteúdo convencional das palavras e, por consequência, seu campo semântico. Dito de outra forma, o enunciado também produz significados a serem analisados pelo historiador. 
Nesse sentido, a dicção do cantor seria um fator essencial para a compreensão da linguagem musical. A esse respeito, Luiz Tatit (2002) afirma que, em muitos casos, a "maneira de dizer" do cancionista sobressai ao que foi dito, ou melhor, ao que foi cantado, uma vez que a sua maneira particular de transmitir ideias e experiências pode ser fisgada pelo ouvinte por meio da melodia. O acesso a esse "discurso de natureza simbólica", criado pelo compositor popular, pode ser alcançado ao estabelecermos uma relação de intertextualidade entre a canção e seu contexto sócio-histórico, com o intuito de conhecermos o "universo polissêmico" que favoreceu tanto a sua criação quanto a sua inserção em uma determinada época e lugar.

Marcos Napolitano (2002) lembra que um dos grandes desafios do historiador seria mapear as camadas de significados próprias da linguagem polissêmica desse objeto de estudo, assim como sua inserção no contexto político em questão. O autor aponta dois parâmetros básicos para análise de uma canção enquanto fonte histórica: o primeiro é o "verbo-poético", que engloba motivos, categorias simbólicas, citações e figuras de linguagem, entre outros procedimentos poéticos e literários. O segundo parâmetro abarca a criação musical: harmonia, melodia, ritmo, arranjo, intérprete, instrumentação, a dicção do cantor e suas variações de cadências, timbres, entonações, ressonâncias, tessituras. Ou seja, por tratar-se de um objeto que congrega uma estrutura poético-musical marcada pela tensão interna constante entre vários aspectos e procedimentos de criação, é necessário analisá-lo em todo o seu conjunto harmônico, articulando seus diversos componentes.

Ao considerar a canção como um "ato linguístico" a ser analisado dentro de seu próprio mundo intelectual e político, o historiador deve analisar os substratos para a compreensão da "gramática da linguagem" utilizada pelo compositor que canta a realidade social à sua volta ou a história do país. Essa análise requer uma atenção redobrada. Koselleck (2012) chama atenção para a diferença entre as narrativas que retratam o fato histórico, as narrativas que relatam o que poderia ter ocorrido ou que se pretendia que ocorresse e as narrativas que não guardam nenhuma relação direta com a realidade existente. Ao historiador cabe a tarefa de saber ler os acontecimentos do passado e os textos sobre o passado em diferentes registros linguísticos. Ou seja, o historiador deve lidar também com os recursos da ficção e sua facticidade. Sobre a relação entre a res factae e a res fictae, o autor afirma que: 
Um poeta pode meter-se nas vestes do historiador, de modo que seu próprio texto não permita mais qualquer determinação de limites, que ele eventualmente procura disfarçar. Pode servir-se de fontes autênticas ou fingidas. Ao fim e ao cabo, pode dar melhores informações sobre as situações ou conflitos históricos do que um historiador jamais as conseguiria dar. (Koselleck, 2012, p.249)

\section{ESQUINAS DO TEMPO}

Nas primeiras décadas do século XX tem início em nosso país um diálogo entre duas das principais tradições de pensamento e interpretação acerca do Brasil: a história e a canção popular. O encontro entre o historiador e o compositor ocorre em um espaço de interseção narrativa em que o conhecimento histórico e a linguagem musical se fundem na tentativa de solucionar uma questão comum a esses dois narradores: evitar que o esquecimento determine o fim da capacidade humana de transmitir as experiências e ações do homem através do tempo, risco que representa a desintegração dos laços sociais e o rompimento do elo entre as gerações. Vez por outra, eles encontram-se para tentar desvendar os mistérios de uma herança sem testamento: quem somos nós? Quais são as nossas origens? Em que país vivemos de fato?

As respostas encontradas são apenas vestígios, fragmentos de uma história não conhecida totalmente. Diante da impossibilidade de se acessar o passado por completo, visto que as vicissitudes do tempo o transformam a cada instante, cabe ao historiador e ao compositor, à moda dos pescadores que mergulham no mar em busca de pérolas preciosas, trazer à superfície do presente pequenos lampejos de memória, metamorfoseados pelo poder da imaginação em pontas de iceberg, peças de um quebra-cabeça, pequenos pontos luminosos a nos guiar na tentativa de montar uma constelação de eventos, fatos, acontecimentos, personagens, ideias, valores, princípios a serem recolhidos e decifrados.

Essa interseção narrativa, criada a partir do diálogo entre a história e a canção popular, é trabalhada no programa Decantando a República como uma espécie de "esquina atemporal", entrecruzamento de tempos em que sucessivas gerações de compositores assumem o papel do historiador para compor canções que visam construir uma rede descontínua de eventos, fatos e personagens presentes na memória social, cultural e afetiva dos brasileiros. As esquinas são por excelência o lugar do encontro. Na cidade, esses espaços são marcados pela 
experimentação de novas possibilidades, abertura para novas direções e pela escolha do melhor caminho a ser seguido.

A esquina nos possibilita uma infinidade de acontecimentos. Sob o signo da liberdade e da astúcia, ela simboliza a capacidade humana de tomar decisões, convite para conhecer o que ainda não foi visto, experimentar o que não foi vivido. Estar em uma esquina também significa correr riscos, aceitar desafios. Por essa razão, ela é habitada pela Fortuna, "a senhora do acaso e da contingência", deusa pagã que governa a inconstância, o inesperado, as vicissitudes do tempo. Seu poder faz da esquina um lugar de insegurança, dúvidas e incertezas. Nas esquinas do tempo, historiadores e compositores fazem dessa interseção narrativa um espaço de criação simbólica capaz de liberar o eco de antigas vozes, alheias ao transcurso habitual da história oficial, que transformam o presente em um campo poroso, lacunar, inacabado. Contudo, nem mesmo a canção é capaz de acordar os mortos, embora possa apaziguar seu sono. Para tanto, a dupla de narradores faz da esquina seu ponto de partida, retomando velhos caminhos para recobrar aprendizados, como os deixados por Heródoto na Grécia Antiga.

Desde os tempos de Heródoto, pai da história e também da geografia, os historiadores voltam seus olhares para o passado com o objetivo de honrar os feitos de Heitor e as glórias de Aquiles. Em outras palavras, lembrar os limites da ação do homem no tempo, seja ele grego ou troiano. Heródoto foi o primeiro historiador que assumiu a tarefa de recordar o que foi por muitos esquecido, por meio do "ver" e do "ouvir dizer de quem viu". Ou seja, ao querer contar a história de um povo ou de uma cidade a partir dos relatos de suas testemunhas no local onde os fatos aconteceram, ele se torna "aquele que investiga passo a passo" em busca de um conhecimento repleto de "espaço e tempo".

Sob os auspícios de Ulisses, o "patrono de todos os viajantes", que fez da viagem uma experiência cognitiva repleta de alteridade e autoconhecimento, Heródoto percorre as cidades grandes e pequenas. Porém, ele as conhece melhor que o herói, já que sabe que o tempo é vicissitude, transformação e mudança. Diferentemente do Aedo - que retira seu conhecimento do sopro mágico com o qual as musas enchem seus ouvidos de sabedoria -, Heródoto "vê por si mesmo" e "sabe, sobretudo, por que viu" ou aprendeu com alguém que tenha visto. 
O olhar "a olho nu" seria, justamente, o fundamento de seu conhecimento - a experiência. Contudo, o discurso oral também possuía seu valor enquanto registro histórico. Em um mundo no qual a palavra escrita ainda não se havia sobreposto ao testemunho oral, a afirmação "eu sei por ter visto e sei por ter ouvido" faz que o "eu ouvi" possa valer tanto quanto o "eu vi”. Nessa época, o termo "história" era sinônimo de "investigação" e o hístor, ou "historiador", seria também uma espécie de juiz, capaz de analisar quais relatos, escritos ou orais, e as respectivas versões muitas vezes conflitantes de um mesmo evento poderiam fazer parte da narrativa da história.

Heródoto inaugurou a narrativa histórica ao percorrer espaços e cruzar fronteiras entre a civilização grega e o chamado "mundo bárbaro". Depois de tantos passos direcionados para além do visto e do vivido, ele tornou-se uma espécie de "homem-fronteira". Ao desprezar as distâncias, esse tipo especial de narrador revela relevos e desníveis, levando consigo as fronteiras de um conhecimento que se estende aos lugares por onde passa, incluindo o novo, o distante, o diferente. Seus olhares procuram, provocam, investigam e interrogam; enfim, quebram certezas. Todo historiador, aliás, deveria abrir mão de todas elas e perseguir justamente o seu oposto: a dúvida.

O historiador seria, portanto, responsável por lembrar o que foi esquecido, recriando a linguagem secreta que habita os espaços fugidios do passado. Nos períodos de crises e agitação social, ele se torna uma sentinela, velando pela memória daqueles que já se foram. Numa operação de resgate do tempo, emerge, em suas palavras, a trajetória de uma nação que deve ser conhecida por todos. Em sua narrativa, nada é tão triste que não deva ser lembrado.

Por meio de sua escrita, o historiador eleva os feitos do homem ao alcance da imortalidade, pois se as experiências humanas vividas no tempo são perecíveis, as lembranças que habitam a história tornam-se imortais. A narrativa do historiador é como uma canção inacabada à espera que alguém possa cantá-la. Essa espera somente chega ao fim quando essas palavras ganham versos e passam a ser acompanhadas por uma melodia que lhe possibilita um descanso merecido ou, quem sabe, um novo amanhecer.

Muitas vezes quem comparece a esse encontro marcado entre as gerações é o compositor, assumindo para si a condição do historiador. Em muitos casos, a canção brasileira se encarregou de cantar o que foi esquecido ou simplesmente renegado pela história oficial. Caso faltem palavras para expressar 
momentos de angústia e indefinição política na história do Brasil, sua escrita ganha força quando auxiliada por notas musicais que irrompem os livros acadêmicos e chegam aos ouvidos da nossa cultura popular. A partir do momento em que as palavras cantadas atingem o fim desse percurso, fica difícil esquecê-las, e o melhor a fazer é interpretá-las.

\section{UMA MATRIZ DE INTERPRETAÇÃO DO BRASIL}

Desde o início do século XX, é própria do compositor popular essa "mania atrevida" de querer se intrometer nos assuntos da política para demonstrar aos brasileiros que seu conhecimento, advindo do cotidiano, onde a força da oralidade é predominante em relação à palavra escrita, também tem algo a dizer, ou melhor, a cantar. Um canto que conjuga verso, arranjo, performance cênica, dicção do cantor e melodia, direcionados à criação de um saber útil e relevante, à disposição daqueles que querem saber "notícias do Brasil", ou mesmo ouvir histórias de tempos passados, quando figuram muitas vezes projetos inacabados, oportunidades perdidas, possibilidades desfeitas, ações espetaculares e sonhos inconclusos. Vem do seu esforço a necessidade de mostrar o Brasil aos brasileiros.

Por volta da década de 1920, o compositor realizou a combinação entre sofisticação musical e poética com o vocabulário popular das camadas suburbanas, quebrando a concepção hierárquica entre "alta" e "baixa" cultura. Entre os anos 1950 e 1960, o cancioneiro popular concentrou os principais debates culturais do país. Desde essa época, a canção brasileira, veiculada pelos suportes oferecidos pela indústria cultural - como o rádio, a televisão e, mais recentemente, a internet - possui uma característica especial: a capacidade crítica do compositor de interpretar a realidade vigente.

Dessa forma, o compositor seria uma espécie de "intelectual da cultura", ou seja, aquele que possui uma percepção aguçada da vida contemporânea e que se utiliza da linguagem das pessoas comuns para expressar seu pensamento sobre as questões próprias de seu tempo e também do passado. A difusão pelos meios de comunicação de massa é uma das características definidoras dessa modalidade de canção. Sua narrativa seria "publicística", ou seja, a linguagem musical no Brasil comenta, por meio dos mais variados gêneros, do samba ao hip hop, fragmentos do cotidiano individual e coletivo, associados 
à vida política e social, em comunicação direta com o povo nas ruas. Segundo Santuza Naves:

A música popular tornou-se, sobretudo a partir da bossa nova, o veículo por excelência do debate intelectual, operando duplamente com o texto e o contexto, com os planos interno e externo. Internamente, à maneira do artista moderno, $\mathrm{o}$ compositor passou a atuar como crítico no próprio processo de composição; externamente, a crítica se dirigiu às questões culturais e políticas do país, fazendo com que os compositores articulassem arte e vida. $\mathrm{O}$ compositor passou a operar criticamente no processo de composição, fazendo uso da metalinguagem, da intertextualidade e de outros procedimentos que remetem a diversas formas de citação, como a paródia e o pastiche. $\mathrm{E}$ ao estender a atitude crítica para além dos aspectos formais da canção, o compositor popular tornou-se um pensador da cultura. (Naves, 2010, p.21)

Ao cantar o país no âmbito da esfera pública, o compositor expõe suas opiniões, agrega comentários, favorece a controvérsia, discute e troca pontos de vista, incorpora novas informações ao debate da época, questiona verdades absolutas. O cancioneiro popular foi capaz de inventar, ao longo do século XX, uma tradição construída a partir de uma multiplicidade descontínua de eventos que vão ganhando novos sentidos com o passar dos anos. A tentativa de forjar no tempo uma relação com a memória capaz de reconhecer, atualizar e transmitir o conhecimento herdado dos antepassados faz parte do esforço do compositor popular em perpetuar sua trajetória virtuosa, além de um legado de interpretação, conhecimento e pensamento crítico acerca do país e do modo de vida de seus habitantes.

Segundo José Miguel Wisnik (2004), em nosso país, a capacidade criativa e o diálogo estabelecido com outras linguagens culturais e com o pensamento social e político fizeram que a canção se constituísse no debate público como uma espécie de "gaia ciência". Ao longo do século XX, o cancioneiro sintetizou a cultura brasileira entre o erudito e o popular; entre o subdesenvolvimentismo e a industrialização; entre as estruturas arcaicas e provincianas e a modernização; entre a cultura de massas e das raízes culturais nativas, o cosmopolitismo e a tradição folclórica. A combinação entre o pensamento intelectual, o questionamento filosófico, o lastro literário e a originalidade musical e poética própria da canção popular acarretou profundas consequências para 
a vida brasileira. Emergiu desse diálogo uma linguagem artística capaz de emitir uma opinião sobre si mesma e sobre um país ainda em busca de um rosto, uma identidade.

O encontro entre o historiador e compositor, portanto, não poderia ocorrer em outro lugar que não fosse a esquina que se configura por meio da própria narrativa. Não há acontecimento histórico sem que exista um ato de linguagem. Os diferentes estratos de experiências adquiridas a partir dele também não existiriam sem uma forma narrativa para transmiti-las. Mas nenhum relato de um evento passado, por mais completo que seja, é capaz de lembrar tudo o que ocorreu a seu respeito. Ou seja, a história e a linguagem - seja ela escrita, oral ou musicada - mantêm entre elas uma relação de incompletude. Desse diálogo, surge um novo tipo de conhecimento, construído entre o discurso histórico e a ficção. Espécie de esquina atemporal, em que realidade e imaginação fundem-se em um novo espaço de experiência, com vistas a outros horizontes de expectativas possíveis.

Misturando versos e sons, o historiador e o compositor transformaram a luta contra a perda da memória em narrativa poética. Mediante "palavras mágicas e discursos multicoloridos", eles provam que mesmo a mais difícil perda poderia ser reparada, se dela pudéssemos contar uma história, ou melhor, compor uma canção. Ainda que os fragmentos de passado estejam à mercê do tempo, é preciso cantar e enfrentar o poder do esquecimento. Como diriam os versos do poeta Thiago de Mello musicados por Monsueto para o disco Manhãs de Liberdade de Nara Leão, em 1966:

\section{Faz escuro, mas eu canto}

Porque a manhã vai chegar

Vem ver comigo, companheiro

A cor do mundo mudar

Ao voltarem novamente suas atenções para a esquina, historiadores e compositores descobrem que o próprio presente, o hoje ou o agora seriam esquinas em que é possível reunir fragmentos de passado e possibilidades de futuro abertas para novos começos; amálgama feita de concreto e sonho, no qual se fundem o real e o imaginário, a história e a canção. Para tanto, é preciso que um terceiro personagem compareça a esse encontro: o ouvinte. 


\section{RÁdio UFMG EducAtiva 104,5 FM}

No mundo atual, acompanhamos de perto o ritmo incessante com que um grande volume de informações é gerado por meio de uma cultura digital cada vez mais instantânea. Nesse contexto, vale apostar na capacidade crítica de ouvintes interessados em saber mais sobre a trajetória política, cultural e social do país. O programa Decantando a República visa colaborar com o ensino de história, no sentido de contribuir para a formação cultural, social e política de seus ouvintes. Mais que a transmissão de conteúdos, o programa propõe uma reflexão acerca do conhecimento histórico e sua contribuição para a construção da cidadania em nosso país.

Em setembro de 2005, a Universidade Federal de Minas Gerais (UFMG) concretizava um antigo projeto: a criação de uma rádio universitária voltada para a produção e a divulgação de um saber que articula as várias áreas do conhecimento, além do campo artístico e cultural, com uma grade de programação musical que valoriza a canção popular, a música erudita e a abertura para novas tendências. A "Estação do conhecimento", como a Rádio UFMG Educativa passou a ser conhecida por seus ouvintes, entrava no ar com uma equipe jornalística voltada para a difusão de informações de interesse público não restrito à comunidade acadêmica. Ao abordar questões sociais, culturais e políticas de âmbito nacional, a Rádio UFMG Educativa representa um novo passo dado pela universidade em direção ao encontro com a sociedade, fortalecendo o seu princípio básico e fundamental de universalização do conhecimento.

A viabilização do projeto foi possível graças à concessão, à universidade, de um canal de transmissão, feita pelo Ministério das Telecomunicações por meio da Empresa Brasil de Comunicações (EBC), que detém o monopólio do serviço de radiofonia no país. A Rádio UFMG Educativa abriu seus trabalhos falando para Belo Horizonte e alguns municípios vizinhos, pelas ondas sonoras, e para o mundo, pela internet. Em 2014, ela aumentou seu alcance de difusão com a instalação de um novo transmissor, vinte vezes mais potente em comparação ao anterior. Isso possibilitou que sua programação pudesse ser ouvida em toda a região metropolitana de Belo Horizonte. Além do aumento do sinal, a implementação do novo sistema foi acompanhada pela modernização de sua 
estrutura física e eletrônica, o que possibilitou à Rádio UFMG funcionar com os mesmos parâmetros técnicos das emissoras comerciais da capital.

Internamente, a Rádio UFMG Educativa desenvolve um importante papel de convergência das diferentes áreas do saber que integram a comunidade universitária. Em sua programação, são veiculados aproximadamente cinquenta programas, produzidos com a participação de professores, alunos e funcionários de departamentos e equipes de pesquisa presentes em todas as unidades acadêmicas, além dos projetos de extensão da universidade. Nesse sentido, os corredores e estúdios de gravação da emissora possibilitam a construção de um conhecimento transdisciplinar aberto para a pluralidade de experiências e a multiplicidade de interações, que não apenas dinamizam o convívio acadêmico, mas também complementam o currículo profissional e enriquecem as relações humanas em sua dimensão de alteridade e interação social.

Dessa forma, a Rádio UFMG Educativa reafirma o compromisso básico assumido pela universidade em criar um espaço de sociabilidade propício à diversidade dos saberes e capaz de ampliar a circulação do conhecimento às amplas camadas da população, em uma realidade na qual nem todos os segmentos sociais tem acesso a educação e cultura, condições básicas da cidadania. Esse processo resulta na democratização do ensino em construção permanente. A Rádio UFMG Educativa reforça o caráter público da universidade por meio de um veículo de comunicação que diminui distâncias, aproxima diferentes experiências de vida e abre novos horizontes de expectativas para alunos, professores, e, fundamentalmente, para o cidadão comum.

\section{UM PROGRAMA SOBRE HISTÓRIA E CANÇÃO}

A criação do programa Decantando a República foi uma parceria estabelecida entre a Rádio UFMG Educativa e o Projeto República: núcleo de pesquisa, documentação e memória, coordenado pela Professora Heloisa Starling, do Departamento de História da UFMG. A equipe de pesquisadores, formada por estudantes de graduação à época, foi responsável pela realização, em 2001, do seminário Decantando a República: um inventário histórico e político da Canção Popular Brasileira, organizado pela referida professora em companhia de José Eisenberg (Iuperj) e Berenice Cavalcanti (PUC-Rio). O evento convidou vários intelectuais de renome nacional para discutir a relação entre a 
narrativa musical e o pensamento político brasileiro próprio do cancioneiro popular ao longo do século XX.

Os textos referentes ao seminário, publicados nos livros de mesmo nome, em 2004, apresentam análises sobre a trajetória do compositor popular, perpassada pela presença constante de determinados temas próprios à tópica do republicanismo, como virtude, liberdade, cidadania, Estado, pátria, nação e bem comum, entre outros (Starling; Eisenberg; Cavalcante, 2004). A utilização da canção popular como fonte de pesquisa para os estudos históricos, além de outras linguagens artísticas - como literatura, cinema, teatro, fotografia e artes plásticas -, foi abordada por esse grupo em outros trabalhos, como organização de banco de dados, exposições temáticas e produção de material didático. ${ }^{1}$

Durante todo o primeiro semestre, até o lançamento oficial da emissora em setembro de 2005, foram realizadas oficinas semanais sobre a linguagem e as técnicas radiofônicas, ministradas pelo jornalista Elias Santos, professor de jornalismo e diretor executivo da Rádio UFMG Educativa. O objetivo era a produção de "pílulas de conhecimento", formato utilizado para a produção de programas radiofônicos com características específicas para despertar o interesse do ouvinte e, ao mesmo tempo, cativar a sua curiosidade, elementos cruciais para a sua participação no processo de construção do saber.

A denominação "pílula de conhecimento" deve-se ao tempo de duração do programa. Em uma programação de rádio, o tempo é precioso. A enorme rapidez com que o ouvinte de rádio e o internauta são bombardeados com informações, muitas vezes efêmeras, causa um movimento ininterrupto de notícias, opiniões, peças publicitárias, discursos variados sobre temas e assuntos diversos. Uma locução muito extensa, mesmo sobre assunto de interesse do público, pode resultar na sua dispersão.

Dessa maneira, para esse programa priorizamos a escrita de um texto sucinto e, ao mesmo tempo ágil e dinâmico, capaz de chamar a atenção do público, mesmo que esse esteja realizando outra atividade, como por exemplo, dirigindo um automóvel ou trabalhando no computador. O exercício de síntese é um dos grandes desafios encontrados pelos pesquisadores responsáveis pela produção do programa. Em termos gerais, o texto escrito para a locução que apresenta o tema em debate possui 1 minuto e meio de duração. Somado ao tempo de veiculação da canção, com tempo médio de 3 a 4 minutos, temos uma "pílula do conhecimento". 
Por essa razão, a linguagem utilizada na locução é uma questão fundamental. Ela deve se caracterizar por interatividade, acessibilidade, objetividade e proximidade ao mundo cotidiano, sem, no entanto, perder a densidade que requer o discurso histórico. O programa Decantando a República foi pensado para alcançar o maior número de ouvintes possível, sem um "público alvo" definido. Nesse sentido, é necessário evitar os chamados "chavões acadêmicos", certo tipo de linguagem específica que restringe o assunto em questão ao círculo fechado do preciosismo academicista.

Conceitos e termos técnicos, sem o devido esclarecimento do que representam, também dificultam a clareza da mensagem. Além disso, o texto de locução deve fugir ao formato tradicional da sala de aula, em que o conteúdo é transmitido aos alunos de forma "professoral". Uma das estratégias para fisgar o ouvinte é, por exemplo, enfatizar como certos procedimentos narrativos próprios da canção popular - como ironias, sarcasmos, metáforas jocosas e jogos de palavras - são utilizados na forma de elementos lúdicos e humorísticos com que compositores populares lançam seus olhares sobre o passado.

É importante ressaltar que os estudantes envolvidos no projeto participam de todas as fases de produção: definição das séries temáticas, elaboração das pautas, pesquisa histórica, seleção de repertório musical, escrita dos textos, locução, acompanhamento técnico no estúdio de gravação. Ou seja, ao exercer as diferentes atividades necessárias para o resultado final do trabalho, os pesquisadores desenvolvem outras habilidades que dizem respeito a um processo transdisciplinar do conhecimento, articulando as áreas da História, Língua Portuguesa e Comunicação. O programa Decantando a República é veiculado diariamente por volta das $10 \mathrm{~h} 15$. A cada semana apresenta um tema específico para debate, em torno do qual cinco canções são apresentadas ao público, sempre em diálogo com o contexto histórico em que foram gravadas.

As séries temáticas produzidas para o programa revelam algumas das visões de história criadas a partir dos mais variados gêneros musicais, como samba, marchinha carnavalesca, samba-enredo, canção caipira, baião, canção de protesto, MPB, rock, repente, reggae, axé music, funk e rap, entre vários outros. Essa riqueza de ritmos proporciona um vasto repertório historiográfico formado por "grandes heróis nacionais", líderes revolucionários, supostos salvadores da pátria, ativistas sociais, lideranças políticas dos mais variados partidos, personagens anônimos do campo e da cidade, malandros e trabalhadores, 
cangaceiros, grevistas, retirantes, homens e mulheres à margem da nação e em luta pela construção da cidadania em nosso país.

A diversidade de pontos de vista e ângulos de visão acerca dos tipos sociais existentes na canção popular é revelada em interpretações contrastantes e, em muitos casos, contraditórias. As ações de um personagem ou determinados acontecimentos históricos são narrados em chaves interpretativas distintas, como a elegia, a exaltação, a sátira, a crônica laudatória ou a pura fabulação. O olhar sobre o passado é acompanhado por nostalgia e saudosismo, por alguns, e por lamento, indignação e revolta, por outros. Desse mesmo modo, a expectativa em relação ao futuro do país é acompanhada por otimismo e sonhos de grandeza, mas também por medo, insegurança e desilusão.

\section{SÉRIES TEMÁTICAS}

A utilização do formato de séries temáticas possibilita que um determinado tema, evento ou personagem histórico ganhe diversas abordagens possíveis. Cada uma delas é apresentada ao ouvinte dentro dos seus marcos cronológicos, com o objetivo de evitar possíveis erros de avaliação histórica. Para a análise de uma canção é preciso, portanto, ir primeiramente à gravação contemporânea ao período histórico em discussão, bem como à interpretação do cantor ou grupo selecionado pela equipe de produção. Nesse sentido, a performance ou o ato performático do intérprete seria também um elemento responsável pelo resultado geral da obra musical.

Esse é, por exemplo, o caso de Aquarela do Brasil, composta por Ary Barroso, canção de grande popularidade que ganhou inúmeras regravações desde que foi lançada em 1939, por Francisco Alves. O programa Decantando a República levou ao ar três interpretações distintas dessa mesma canção com o objetivo de discutir a construção da nossa identidade nacional em três diferentes momentos da trajetória política do Brasil ao longo do século XX. Cada uma dessas regravações nos permite, à sua maneira, analisar questões particulares ao contexto histórico específico em que ocorreram. A interpretação original foi realizada durante o Estado Novo (1937-1945), época não apenas de intensos debates sobre a identidade do país, como também da tentativa de autolegitimação política realizada pelo governo de Getúlio Vargas desde que tomou o poder em 1930. 
A gravação de Francisco Alves, considerado o "rei da voz", naquele contexto, caiu como "uma luva" para os intentos da ditadura varguista. Ary Barroso não apenas inventou o samba-exaltação como definiu seu paradigma. Enquanto a letra enaltecia o Brasil, seu povo, suas cores, tradições e riquezas naturais, a melodia sincopada dava o tom de grandiosidade da introdução ao final apoteótico. O resultado foi a popularização de uma visão romântica e grandiloquente do país, ratificada pela voz empostada de Francisco Alves com um acompanhamento de orquestra, com regência de Radamés Gnattali, que reforçava ainda mais o tom de monumentalidade da composição. Essa primeira gravação foi ao ar em um programa que situou a importância da obra de Ary Barroso para a história da canção popular, além de contextualizar o lançamento de Aquarela do Brasil no cenário cultural e político da década de 1930.

Ao longo dos anos, o olhar otimista lançado pelo compositor sobre o país gerou polêmicas. Para os críticos que apontavam o traço ufanista de Ary Barroso, Aquarela do Brasil apaziguava contrastes, harmonizava conflitos, tornando legítima uma nação que se emudecia perante desigualdades e injustiças como, por exemplo, o racismo. O segundo programa sugere ao ouvinte algumas pistas sobre as novas tonalidades oferecidas por Elis Regina, em uma gravação de 1969:

Há muito tempo o compositor popular se pergunta que pais é este. Desde os tempos da Aquarela do Brasil de Ary Barroso essa é uma história que vem dando samba e dos bons. Na década de 1930, o Brasil pintado por Ary Barroso ganhava tons orquestrais e se fundia a uma cadência hora marcial, hora gingada que brincava com o colorido da mulata e do pandeiro. Com as cores do país, Ary Barroso parecia querer pintar também o paraíso em verde e amarelo. Porém, em qualquer aquarela, é preciso ter cuidado para não errar a mão e carregar demais nas tintas ou, ao contrário, pintar um cenário esmaecido e sem definição. Na festa de cores que é a Aquarela do Brasil, Elis Regina também dá o seu pitaco. Usando da mais pura malícia, Elis Regina, em 1969, apresenta à nação o colorido que faltava naquela aquarela. Isso porque na voz da cantora não faltou a cor da Nega do cabelo duro. Com vocês, Elis Regina.

Logo em seguida ouve-se a interpretação lançada pela cantora em companhia do jazzista Toots Thielemans em uma gravação ao vivo realizada durante um show da dupla na Suécia, em 1969. Contudo, em meio aos versos 
de Aquarela do Brasil é possível notar a presença da canção incidental Nega do cabelo duro, de Rubem Soares. A intervenção da cantora apresenta de forma expressiva a personagem de cor negra ao contrário dos personagens nomeados de forma oblíqua ou pouco definidas como "morena sestrosa", "mulato inzoneiro" e "Brasil, lindo e trigueiro" presentes na letra. A única exceção seria a "mãe-preta", personagem que parece, à primeira vista, não oferecer nenhum tipo de ameaça à ordem escravocrata. Na gravação, a Nega do cabelo duro é introduzida de forma habilidosa em meio a sutilezas e nuanças pela cantora. A partir daí, Elis Regina brinca com a melodia em um jogo de sons que mistura o ritmo e sua própria dicção no verso "Qual é o pente que te penteia", criando uma ambiência musical totalmente despojada do tom grandiloquente da gravação original de 1939. O acento enfático no termo "nega do cabelo duro" expressão pejorativa que denuncia o preconceito racial associado a uma suposta inferioridade estética - também é reforçado por Elis Regina.

A terceira gravação de Aquarela do Brasil veiculada pelo Decantando a República é datada de 1980 e foi realizada também por Elis Regina. Nesse ano, o Brasil assistia a um intenso movimento de luta por direitos. No ano anterior, fora sancionada a lei de anistia aos presos políticos que garantia o retorno ao país dos exilados e perseguidos pela ditadura militar. No início da década de 1980, os militares assistiram ao fortalecimento da oposição que passou a pressionar a ditadura em várias esferas sociais e políticas. Apesar de viver ainda sob o julgo da repressão, a população voltou às ruas das cidades em passeatas e protestos. Em termos sociais, a ditadura assistiu também à reorganização da sociedade civil através do movimento sindical, movimento feminista, movimento estudantil, movimento negro e movimentos de moradores de vilas e favelas, entre outros. A locução desse terceiro programa apresenta a segunda gravação de Elis Regina para Aquarela do Brasil, retomando a discussão sobre a visibilidade social atribuída pela cantora a outro personagem em luta por seus direitos naquele contexto histórico:

Elis Regina gravou Aquarela do Brasil duas vezes. A primeira foi em 1969. Nessa oportunidade, a cantora aproveitou para lembrar aqueles que foram esquecidos por Ary Barroso em seu retrato multicolorido do Brasil. Em sua interpretação, Elis Regina chama a Nega do cabelo duro para participar da festa de cores pintada pelo compositor. Na segunda ocasião, em 1980, a cantora divide os microfones com outros per- 
sonagens que nem sequer são mencionados na aquarela. Por meio do arranjo, Elis Regina introduz na canção de Ary Barroso uma tribo indígena inteira. Ou seja, na Aquarela do Brasil retocada por Elis Regina, o que não faltou foram as cores e os sons do povo brasileiro. Com vocês Aquarela do Brasil, em gravação de 1980.

Nessa interpretação da composição clássica de Ary Barroso, incluída no disco duplo Saudade do Brasil, a cantora traz uma segunda inovação em termos de arranjo. Desta feita, a canção é precedida por um canto indígena entoado como um grito de guerra que toma para si a primazia sonora, transformando a própria Aquarela do Brasil em canção incidental. Essa inversão de lugares entre a voz que enuncia e o personagem enunciado pela canção - presentificado pelo canto de guerra indígena com seus gritos e o entoar dos tambores e instrumentos de sopro - descontrói metaforicamente a leitura que, muitas vezes, transfigura a história do Brasil com seus conflitos, silêncios e ausências, em uma trajetória harmônica e apaziguadora em nome da unidade nacional ou uma pretensa "democracia racial". Oferecer visibilidade aos excluídos seria uma subversão política e musical praticada por Elis Regina. Ação capaz de conferir voz aos personagens mantidos em silêncio, à margem da história do Brasil.

Ao longo da década de 1970, diversas tribos indígenas começam um processo de organização em associações com o objetivo de melhor representar seus interesses junto às instituições da sociedade civil, além de chamar a atenção da opinião pública para questões fundamentais como a invasão das terras indígenas. Na época, as nações da região do Xingu, sob a liderança do cacique Raoni, estavam em pé de guerra com a inoperância da Funai e a omissão do governo federal diante das constantes ameaças aos direitos das tribos indígenas. Criado em 1961, o Parque Nacional Indígena do Xingu, a mais famosa reserva do mundo, passa a sofrer sérias ameaças, por volta de 1980, com as discussões em torno do projeto de construção da Usina Hidrelétrica do Belo Monte. Em 1984, Raoni chegou a ser recebido, em Brasília, por Mário Andreazza, ministro do Interior. O cacique compareceu à reunião armado e pintado nas cores da guerra, fazendo duras críticas ao governo.

Outra liderança indígena importante, no início dos anos 1980, foi Mario Juruna, que ficou famoso ao reivindicar junto à Funai maior atenção para os problemas enfrentados pela população indígena no Brasil. A principal delas era a demarcação das terras. Indignado com a omissão da Funai, Juruna decide 
viajar para Brasília exigindo pessoalmente respostas para suas reivindicações. Uma de suas armas era o gravador. Juruna registrava todas as reuniões e audiências nas quais várias promessas eram feitas em favor de seu povo, mas poucas foram cumpridas. Dessa maneira, ele denunciava o descaso e a falta de coerência das autoridades em relação à causa indígena. Em 1980, enfrentou a perseguição das autoridades brasileiras para participar do Tribunal Bertrand Russell, na Holanda, onde representou o país ao lado do antropólogo Darcy Ribeiro, nos julgamentos de crimes cometidos contra os povos indígenas.

As duas versões de Elis Regina para Aquarela do Brasil lançam luz sobre o conflito existente em nossa sociedade desde a ocupação do território brasileiro, como também oferecem voz ao diferente, ao ausente, ao silenciado. Ou seja, elas propõem uma solução possível para a cidadania no Brasil: a inclusão e o respeito ao outro.

\section{CONSIDERAÇÕES FINAIS}

A aposta do programa Decantando a República, em mais de 10 anos de atividade na programação da Rádio UFMG Educativa, consiste em oferecer as armas necessárias a um combate ético: a capacidade de reelaborar de forma autônoma os vários discursos acerca da história do Brasil. Isso significa que cada ouvinte saiba estabelecer critérios e balizas próprias de avaliação para distinguir, analisar e julgar qual a melhor compreensão e utilização de um conteúdo veiculado pelos diversos suportes de comunicação, como rádio, internet, jornal impresso, televisão, revistas e livros.

As ideias, os princípios e os valores discutidos ao longo dos programas são lançados em forma de problematização ao público, na tentativa de que ele se aproprie desses mesmos elementos conceituais, aproximando-os de seu dia a dia imediato para, a partir dessa decodificação, propor soluções para seus questionamentos, construindo assim uma visão particular de mundo. A canção popular contribui com esse propósito, na medida em que conhece, como nenhuma outra linguagem no país, o cotidiano formado por desejos e medos, angústias e fantasias, expectativas e desilusões do povo brasileiro. Seria em diálogo constante com o historiador e o compositor popular que o ouvinte aplicaria diretamente em sua realidade específica o conhecimento gerado a partir da interação e do convívio entre a história, a canção e sua própria vida. 


\section{REFERÊNCIAS}

ALVES, Maria Helena M. Estado e oposição no Brasil (1964-1984). São Paulo: Edusc, 2005.

ARENDT, Hannah. Entre o passado e o futuro. Trad. Mauro Barbosa de Almeida. São Paulo: Perspectiva, 1988.

AUSTIN, John. Quando dizer é fazer: palavras e ação. Trad. Danilo Marcondes de Souza Filho. Porto Alegre: Artes médicas, 1990.

BALTA, Marcos. Rádio escolar: uma experiência de letramento midiático. São Paulo: Cortez, 2012.

BENJAMIN, Walter. Magia e técnica, arte e política: ensaios sobre literatura e história da cultura. Trad. Sérgio Paulo Rouanet. São Paulo: Brasiliense, 1987.

CASTRO, Maria Ceres et al. Segundo Encontro Nacional de Rádio Ciência. Belo Horizonte: Cedecom/UFMG, 2008.

CONTIER, Arnaldo. Música e História. Revista de História, São Paulo, n.119, p.69-89, jul./dez. 1988. Disponível em: http://www.revistas.usp.br/revhistoria/article/ view/18572.

HARTOG, François. O espelho de Heródoto: ensaios sobre a representação do outro. Trad. Jacyntho Lins Brandão. Belo Horizonte: UFMG, 1999.

. Regimes de historicidade: presentismo e experiências do tempo. Trad. Andréa Souza de Menezes. Belo Horizonte: Autêntica, 2013.

JASMIN, Marcelo; FERES Jr, João. (Org.) História dos conceitos: diálogos e perspectivas. Rio de Janeiro: Ed. PUC-Rio, 2006.

KOSELLECK, Reinhart. Futuro passado: contribuição à semântica dos tempos históricos. Trad. Wilma Maas, Carlos Pereira e César Benjamin. Rio de Janeiro: Ed. PUC-Rio; Contraponto, 2012.

MARTINS, Franklin. Quem foi que inventou o Brasil? A música popular conta a história da República. São Paulo: Nova Fronteira, 2015. vols. I, II e III.

MATOS, Cláudia; TRAVASSOS, Elizabeth; MEDEIROS, Fernanda (Org.) Ao encontro da palavra cantada: poesia, música e voz. Rio de Janeiro: 7 Letras, 2001.

MELLO, Zuza H. de; ZEVERIANO, Jairo. A canção no tempo: 85 anos de músicas brasileiras. São Paulo: Ed. 34, 1999. vols. I e II.

MIRANDA, Wander. Brutalidade e jardim: tons da nação na música brasileira. In: STARLING, Heloisa; EISENBERG, José; CAVALCANTE, Berenice (Org.) Decantando a república: inventário histórico e político da canção popular brasileira. Rio de Janeiro: Nova Fronteira, 2004. vols. 1, 2 e 3.

MORAES, José Geraldo V. História e música: canção popular e conhecimento histórico. Revista Brasileira de História, São Paulo, v.20, n.39, p.203-221, 2000. 
Disponível em: http://www.scielo.br/scielo.php?script=sci_arttext\&pid=S010201882000000100009\&lang=pt.

NAPOLITANO, Marcos. História \& Música. Belo Horizonte: Autêntica, 2002.

NAVES, Santuza. Canção popular no Brasil. Rio de Janeiro: Civilização Brasileira, 2010.

NETO, Lira. Getúlio. São Paulo: Companhia das letras, 2012-2014. vols. I, II e III.

POCOCK, John. Linguagens do ideário político. São Paulo: Edusp, 2003.

PRADO, Magaly. História do rádio no Brasil. São Paulo: Ed. da Boa Prosa, 2012.

SKINNER, Quentin. Significado y comprensión en la historia de las ideas. Prismas, Revista de historia intelectual, Buenos Aires: Universidad Nacional de Quilmes, n.4, 2000.

STARLING, Heloisa; EISENBERG, José; CAVALCANTE, Berenice (Org.) Decantando a república: inventário histórico e político da canção popular brasileira. Rio de Janeiro: Nova Fronteira, 2004. vols. 1, 2 e 3.

TATIT, Luiz. O cancionista: composição de canções no Brasil. São Paulo: Edusp, 2002.

WHITE, Hayden. Meta-História: a imaginação histórica do século XIX. Trad. José Laurenio de Melo. São Paulo: Edusp, 1992.

. Teoria literária e escrita da história. Revista Estudos Históricos, Rio de Janeiro, v.7, n.13, p.21-48, 1994. Disponível em: http://bibliotecadigital.fgv.br/ojs/index.php/reh/article/view/1978.

WISNIK, José Miguel. Sem receita: ensaios e canções. São Paulo: Publifolha, 2004.

\section{NOTA}

${ }^{1}$ Entre 2001 e 2005, o Projeto República/UFMG realizou atividades como: montagem de um banco de dados sobre a produção fonográfica brasileira entre 1889 e 2001; pesquisa musical para a exposição Juscelino Prefeito (1940-1945) no Museu Histórico Abílio Barreto (MHAB); produção do CD-ROM Visionários: a imaginação republicana nas Minas dos séculos XVIII, XIX e XX em parceria com o Museu da República; pesquisa documental para a exposição Brasil 1964-1984-2004, realizada durante o $5^{\circ}$ Salão do Livro de Minas Gerais em parceria com a Fundação Municipal de Cultura de BH; produção da exposição Liberdade Essa Palavra, para as comemorações do $76^{\circ}$ aniversário da UFMG; produção do CD-ROM Sentimento de reforma agrária, sentimento de república em parceria com o Nead/MDA; entre outros trabalhos.

Artigo recebido em 2 de novembro de 2016. Aprovado em 5 de janeiro de 2017. 